\title{
Moment capacity of connection with the additional top and seat angles to slab and column panel of cold-formed steel section
}

\author{
Sutanto Muliawan', Anis Saggaff', Mahmood Bin Md Tahir ${ }^{2}$, Saloma $^{1 *}$, Muhammad Firdaus ${ }^{3}$ and \\ KM Aminuddin ${ }^{1}$ \\ Civil Engineering Department, Faculty of Engineering, Universitas Sriwijaya, Inderalaya, Indonesia ${ }^{1}$ \\ Institute for Smart Infrastructure and Innovative Construction (ISIIC), Construction Research Centre (CRC), School \\ of Civil Engineering, Universiti Teknologi Malaysia, Johor Bahru, Malaysia ${ }^{2}$ \\ Civil Engineering Department, Faculty of Engineering, Universitas Persatuan Guru Republik Indonesia, Palembang, \\ Indonesia $^{3}$
}

Received: 22-May-2021; Revised: 20-August-2021; Accepted: 26-August-2021

(C)2021 Sutanto Muliawan et al. This is an open access article distributed under the Creative Commons Attribution (CC BY) License, which permits unrestricted use, distribution, and reproduction in any medium, provided the original work is properly cited.

\begin{abstract}
The application of Cold-formed Steel (CFS) in construction works increased significantly. Recently this material is commonly used as a non-structural component. However, the research on CFS as a structural component still needs more comprehensive studies. This paper presents the parametric study of three connection types between CFS slab and column panel. It consists of: a) Gusset plate connection only (Isolated Joint Test (IJT)-01), b) Gusset plate with an additional seat angle (IJT-02), and 3) Gusset plate with additional top and seat angles (IJT-03). A T-shaped gusset plate was selected for all three connections. This current study investigates the moment capacity of the connection by combining the gusset plate with an additional top-seat angle. The dimension size of the lipped channel is C12524, and the top-seat angle is L1601607. The gusset plate thickness is $4 \mathrm{~mm}$ with M10 bolts. According to the component method, the assumption of el astic behavior is proposed in this paper (BS EN 1993-1-8 and BS EN 1993-1-3). The calculation results for each specimen confirm that IJT-03 is superior to IJT-01 and IJT-02. The failure mode of IJT-03 is predicted to happen at the top angle cleat due to the bending moment.
\end{abstract}

Keywords

Cold-formed steel connection, Top-seat angle, Connection moment capacity, T-shaped plate connector, Slab, Column panel connection.

\section{Introduction}

Cold-formed Steel (CFS) is currently used as the alternative material of Hot-Rolled Steel (HRS). One of its benefits is that the CFS has a lighter weight rather than HRS. The CFS is produced by forming the thin plate into some type of section at room temperature. CFS is beneficial in daily life; it could be used as the purlin, roof truss, roof cover, composite deck slab, wall panel, racking, and structural framing. Due to its advantages, the demand for CFS usage in construction works increases significantly. So CFS production becomes more massive [1]. On the other side, the CFS has disadvantages; it is instability because of the thin plate behavior. The CFS section tends to buckle when it is subjected to a more significant load [2].

\footnotetext{
*Author for correspondence
}

1005
Several type connections could be utilized for the beam-column connections of CFS. It commonly uses the screw as the connector to connect the roof truss component of the CFS because it is quick and straightforward in installation. In the primary structural connection, such as beam to column connection, the screw connection has some installation problems. The strength to resist the load in the structural component is deficient. So, the proposed bolted connection with slip-in gusset plate on beamcolumn connection is conducted in this study.

There are few studies about the non-composite connection research on CFS as the structural component, which is a beam-column connection [37].

Aminuddin et al. [3] has studied rectangular slip-in gus set plate configurations with rectangular shapes for 
the bolted connection. It continues to make another connection by combining the flange cleat with a similar gusset plate fromhis previous research [4]. The other gusset plate shapes were haunched gus set plate [5] and T-Shaped gusset plate [7]. The welded connection for CFS has been conducted by Hanisha and Kishore [6].

The composite connection is an improvisation from the non-composite connection. There is some component that observed in composite connection which is slab, beam, and column. The study of the composite connection of CFS [8-11] involves a concrete material with various compressive strengths by range $\mathrm{fc}^{\prime}=30 \mathrm{MPa}$ up to $\mathrm{fc}^{\prime}=43 \mathrm{Mpa}$. All of the concrete was conventional concrete. The combination of a rectangular gusset plate and bolted connection were used in the study $[9,10]$, and the combination of seat angles with haunched gusset plate has been studied $[8,11,12]$.

There are additional flange cleats in both studies of non-composite and composite specimens of CFS [4, 8 , 11]. The purpose of additional flange-cleat is related to quick and easy installation and avoids the welding process, which is expensive. Some research combines the composite slab with CFS as a primary beam [1317].

Two types of connection were observed on the connection of encased beam in slab-column connection. First, the gusset plate only [7] and the combination of gusset plate with additional bottom flange cleat connection [18]. As a result, the additional bottom flange cleat could improve the moment capacity of the connection. For further research, it is necessary to improve the recent connection with a new proposed connection. The proposed connection was a combination of a gusset plate with a top-seat angle connection.

This paper covers a comparis on of moment capacity between the connection with additional top and seat angles (Isolated Joint Test (IJT)-03), the connection with additional seat angles only [18] (IJT-02), and the connection without a flange cleat connection [7] (IJT01). This study aims to improve the slab-column panel connection of its moment resistance by combining the gusset plate with the top-seat angel on the connection in specimen IJT-03. This study's major contribution is the development of cold-formed steel as the structural component, which is still rarely carried out.
Besides the analytical calculation, this paper also presents the proposed experimental procedure for future study. The result and discussion of this study could be a reference for the further study of CFS to improve the moment capacity of the Cold-formed steel connection. The experimental procedure proposed in this paper could be a consideration for future studies.

\section{Literature review}

The massive production of CFS has recently made the CFS more popular in its usage. CFS has a thinner cross-section rather than HRS. However, it makes CFS has lack stability [2]. Furthermore, due to its weakness, the study of CFS as the main structural component is still very few. Some CFS experiments have been conducted within a parametric analys is and experimental method in the IJT system. Some research has experimented with the IJT for the non-composite [3-5] and the composite [8-12].

IJT test for the connection of beam to column connection is investigated by Aminuddin et al. [3] with $10 \mathrm{~mm}$ thick rectangular gusset plates. The research methodology used in this study was an experimental and parametric analysis. The beam of the CFS section had various dimensions and the column had only one dimension. The result shows that the beam depth configuration needs further study to obtain the ductile behavior of the connection. Aminuddin et al. [4] continued their study by combining a similar gusset plate with the top-seat angle to improve the connection strength. From the study [3, 4], it could be concluded that the moment capacity and connection stiffness have been improved by adding the top-seat angle in the connection.

Firdaus et al. [5] improvised the specimen with another type of haunched gusset plate with additional top, seat, and web angle in the connection. The cross section dimension of the beam and column was similar to Aminuddin's study [3,4]. The haunched gusset plate was proposed to increase the strength of connection rather than of the rectangular one. In this study, there were six specimens investigated. These six specimens were divided into two groups with two types of connections: gusset plate only and gusset plate combined with flange and web cleat. Each type of connection has three specimens. The moment capacity increased by $20 \%$, and stiffness increased by $30 \%$ using the additional angle. It could be concluded that the top, seat, and web angle have improved the connection strength. The other study of non-composite connection was conducted by Patil et al. [19], which used four various specimens. In the study, different 
types of connections and different dimensions of thickness of the structural element were used. The methodology used was an experimental and finite element method. The specimen with a 2 mm thickness and with angle section showed a higher moment capacity.

The instability of the CFS section was happened due to its slenderness. To overcome the instability of the CFS section, the installment of the composite element integrated into the beam component could affect a greater stiffness of the connection. Since there was very little information about the composite connection, a comprehensive investigation was conducted by Firdaus et al. [8, 11, 12]. The study about the seat angle in composite connection $[8,11]$ could improve the moment capacity by $8 \%$ with a ratio of 1.06. The stiffness are improved by $17 \%$, with a ratio of 1.19. The connection becomes the full-strength behavior by the influence of the seat angle. Sulaiman et al. [10] had studied the other beam-column composite connection. In this paper, there was a comparison between the composite and noncomposite connection of CFS. The result of the study stated that the composite joint had a higher ultimate load capacity and higher moment resistance than the non-composite connection. Firdaus et al. [20] also proposed a programming tool to calculate the strength of CFS composite connection. The proposed program has simplified the calculation methodology based on Eurocode 3: BS EN 1993-1-8: 2005 and Eurocode 4: BS EN 1994-1-1: 2004. The analysis has been performed with various dimensions.

The composite beam with CFS material was investigated by Salih et al. [17]. The configuration of the beam was installed with the bolt connection through I-shape and box-shape. For the slab part, it used self-compacted concrete as a composite material. The U-shape rebar is installed to composite behavior within the beam, slab, and concrete component. The result has shown that the I-shape profile in the bending test has a $24.2 \%$ larger moment capacity than the box shape with a similar configuration. The properties of I-shape CFS provides higher moment inertia than the box shape, and it provided economic savings.

The other study about composite slabs was conducted by Bamaga et al. [21]. The composite beam is variated in the type of shear connector and beamthickness. The study concluded that the beam specimen is significantly affected by the type of shear connector, and the thicker the beam profile also provides a higher strength capacity.
Shi et al. [22] has conducted the flexural test on composite beam. It had a variation in the concrete slab and type of shear connection. There were two types of concrete used in the study. First, the Gypsum-based Self-leveling Underlayment (GSU), and second the Lightweight Concrete with Fine Aggregate (LCFA). The shear connector variation with three types of connectors. The full-scale experiment was a four-point loading test. The failure mode of shear buckling on the joist web location occurred to all specimens. The combination of two types of the shear connector could provide a higher moment capacity.

In Lawan et al. [16] has demonstrated the flexural performance of CFS beam with various shear connectors. The four-point bending test is conducted, and it shows that the composite CFS beam is adequate as a structural member. The type and design of the shear connector significantly influence the beam moment capacity $[16,17,22]$. The study of Lawan et al. [23] has discussed CFS as a sustainable material for a structural element. As the beam element, the composite CFS beam has increased the flexural beam capacity. The application of CFS composite beam has a limitation in small and medium buildings.

The study of concrete slab with the CFS section as reinforcement was carried out by Qiao et al. [24]. It was a new approach to use the CFS as reinforcement of structural components. Likewise, the concrete, integrated with CFS could reduce the instability due to the thinness of the CFS section. The presence of the concrete, integrated with CFS could reduce the concrete volume. This research method was an experimental and finite element with two kinds of specimens. There were four lines (CS-1) and three lines (CS-2) reinforcement of the CFS section. CS-1 with many CFS elements provides superior performance rather than CS-2. In this research, it had been confirmed that the CFS element could substitute the rebars in the slab.

Puluhulawa [25] had researched CFS as slab strengthening with variations of the shear connector. There are two types of shear connectors, which are Epoxy Sikadur CF-31 and Dynabolt M10. The results show that the use of epoxy has increased the stiffness of the strengthened slab, and the dynabolt role could improve the slab in carrying the bending load.

Muliawan et al. [7] studied the slab-to-column connection using parametric analysis. Based on previous research, this kind of calculation procedure is not available. Moreover, the composite slab 
application as the structural component of the building part could only be used if the connection provides such an adequate strength to resist and transfer the load from slab to column. CFS profile in the case was C12524. The gusset plate thickness used in this study was $4 \mathrm{~mm}$ in the form of a T-Shaped gusset plate. The variable in the studies was the bolts that were variated. The compatible bolts that could be used for the connection were M10 bolts.

The other research was conducted by Muliawan et al. [18] with additional seat angle to the column-slab connection.

The gusset plate configuration was similar to Muliawan et al. [7]. They were related to the previous study on the connection between a slab and column of CFS section. Overall, it was shown that the additional bottom flange cleat could improve the moment capacity of the connection.

\section{Methods}

There are three kinds of specimens used in this study. All of the specimens have the typical gusset plate configuration with a T-shaped form. The only gusset plate connection is conducted in IJT-01 [7]. The combination of seat angles and the gusset plate is in specimen IJT-02 [18], and IJT-3 is a specimen with a gusset plate combined with the top-seat angle in the connection. The specimen is shown in Figure 1 with an is ometric view. Figure 1 also shows the dimension of the specimen. It shows where the location of the top-seat angle in the connection. There is one flange cleat on the top and one on the bottom on the side of the specimen. In the middle part, it has two flange cleat on the top and two on the bottom, because in the middle has a double channel lip. All specimens have a similar column panel dimension $(\mathrm{h}=3000 \mathrm{~mm}$ and $\mathrm{b} 1$ $=1000 \mathrm{~mm})$ and similar slab dimension $(1=1000 \mathrm{~mm}$ and b2 $=1000 \mathrm{~mm})$. In Table 1, it shows the difference between the connection. IJT-03 is the proposed connection with this study.

Figure 2 shows the assembly of the IJT-03 specimen in Construction Research Center Laboratorium, University Teknologi Malaysia, Malaysia. The specimen shows a non-composite connection type. The specimen was laid down on the floor before it was installed on the frame rig.

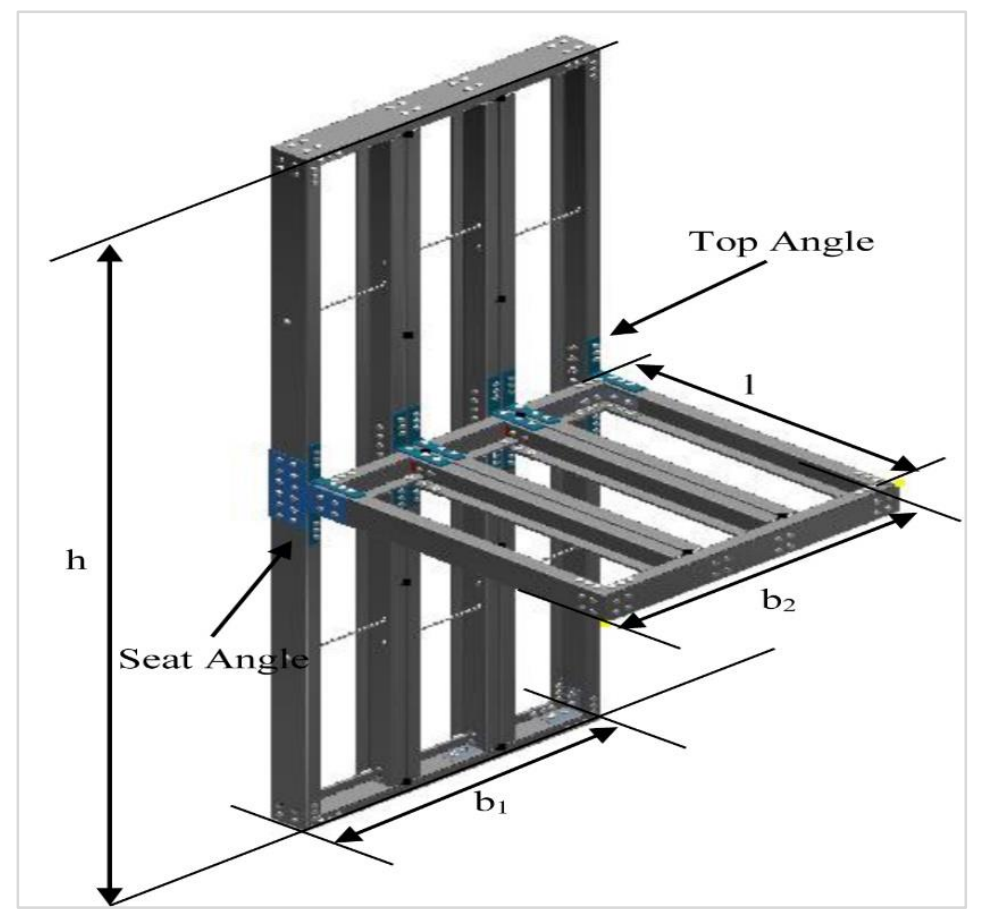

Figure 1 IJT-03 is ometric view 
Table 1 Specimen variation

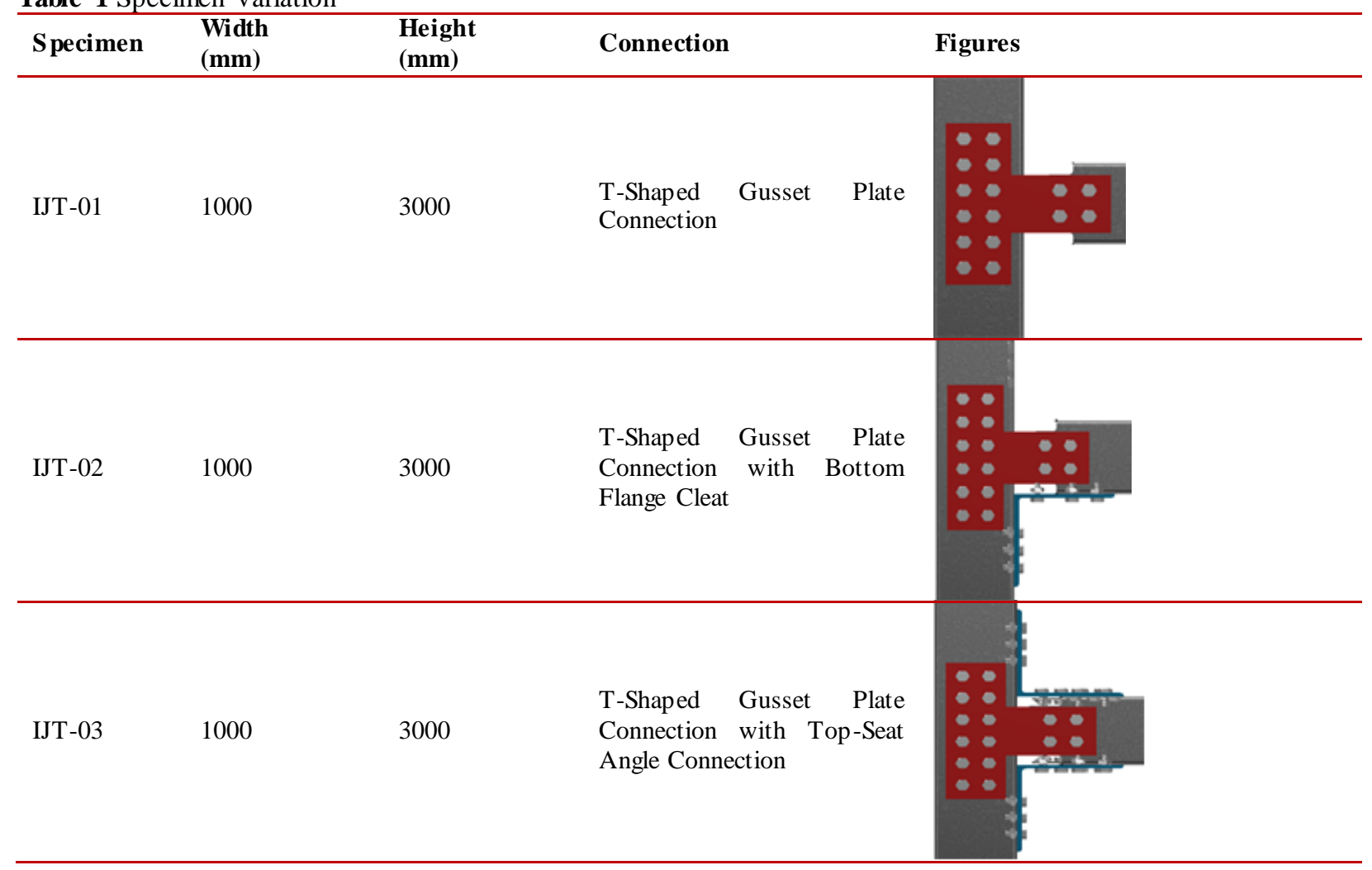

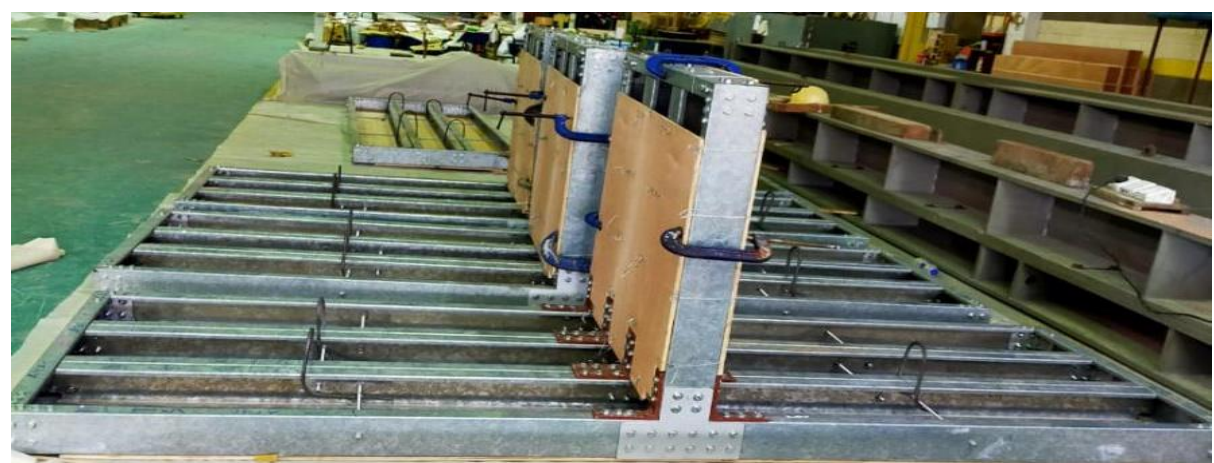

Figure 2 Experimental specimen for IJT-03

Figure 3 shows the cold-formed steel profile utilized in this study. It shows that the CFS dimension and mechanical properties are typical of the previous study $[7,18]$. The specimen's side part utilizes a single CFS, while the middle part has a double channel lip with a back-to-back configuration in the column and slab. For CFS profile design strength is $\mathrm{Fy}=530 \mathrm{MPa}, \mathrm{Fu}$ $=590 \mathrm{MPa}$. 
Sutanto Muliawan et al.

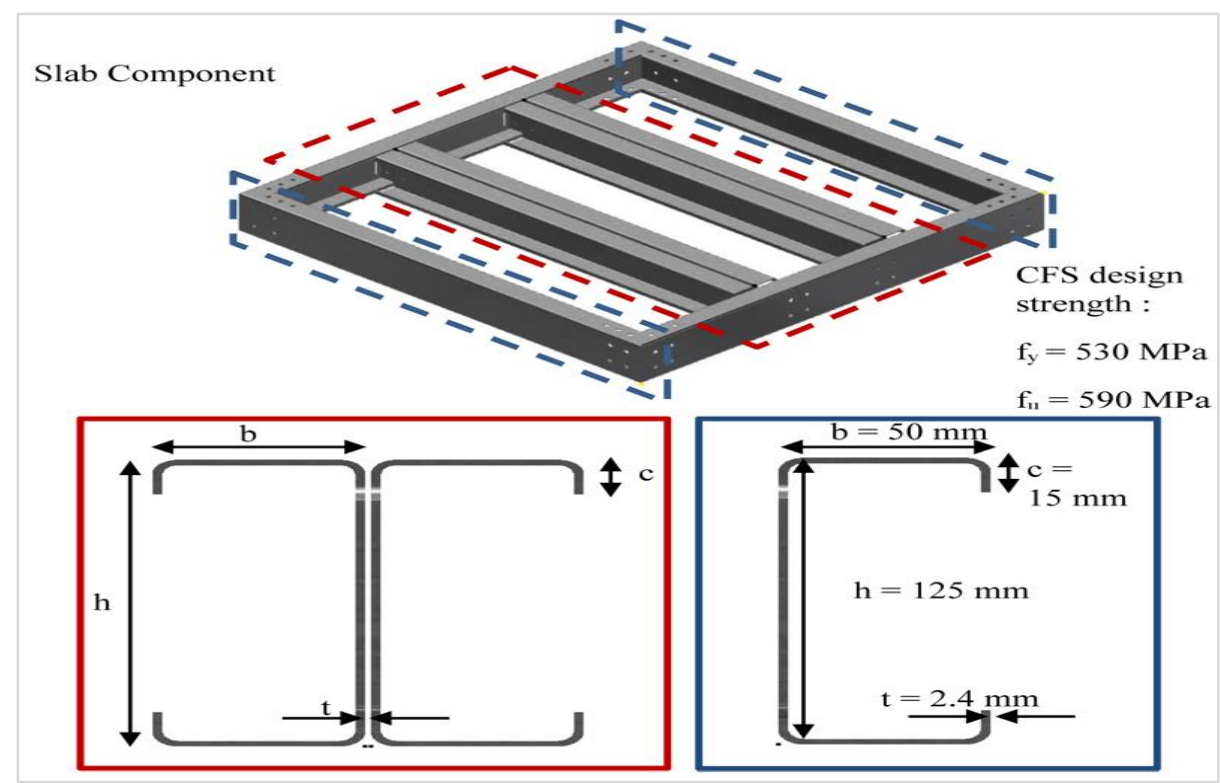

Figure 3 Cold-formed steel section

A bolted T-Shaped gusset plate connection was installed on all specimens, as explained in Table 1. BS EN 1-8:2005 [26] has become the reference for the bolt mechanic properties. The M10 bolts with grades 8.8 are applied in all specimens. The range validity of the bolt has been calculated in a previous study $[7,18]$. The T-shaped quality is S355 grade according to BS EN 1-1: 2005[27] with a thickness of $4 \mathrm{~mm}$.

The flange cleat quality was grade S355, identical to the bottom flange cleat grade on the previous research [18]. The dimension of the flange cleat is shown in Figure 4. It has a top angle and seat angle. The dimension between the top and seat angles is typical with $\mathrm{b}=160 \mathrm{~mm}, \mathrm{~h}=160 \mathrm{~mm}$, and thickness $7 \mathrm{~mm}$. The flange cleat in IJT-02 and IJT-03 have a similar type of flange cleat. IJT-02 has a six flange cleat, while IJT-03 has twelve flange cleats.

BS EN 1993-1-8:2005 is the reference for the component method calculation. Figure 5 shows the flowchart of the study. The first step is collecting all the component data. Then, the parametric study is conducted to calculate the moment capacity of the connection. After the calculation has finished, the IJT03 specimen compares to the previous study [7, 18].

IJT-01 and IJT-02 have been calculated elsewhere [7, 18]. The calculation gives the output of predicted moment capacity its failure mode. This paper is focused only on IJT-03 analysis with top and seat angles on the connection.
For the IJT-03 specimen, the first step is to analyze the gusset plate moment capacity. The gusset plate capacity is calculated just like IJT-01 [7]. For top-seat angle, moment capacity in IJT-03 is calculated based on the component method. There is a column web panel in shear, the column web panel in compression, beam flange and web in compression, bottom angle leg in compression, bottom angle leg in bearing, bottom beam flange in bearing, bottom angle bolt in shear, column flange in bending, column web in tension, bolt in top angle leg in bearing, bolt in top beam flange in bearing, bolt-in shear at the top flange of the beam, and angle cleat in bending (top angle), and angle cleat in tension (top angle).

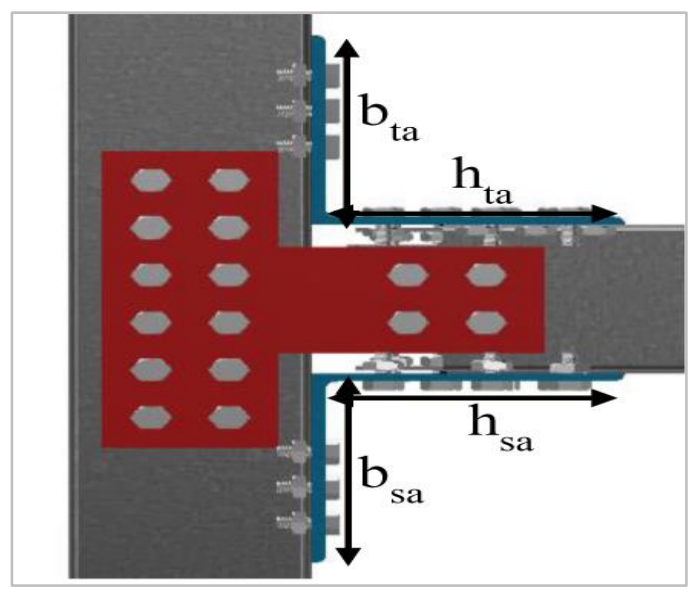

Figure 4 Flange cleat dimension [18] 


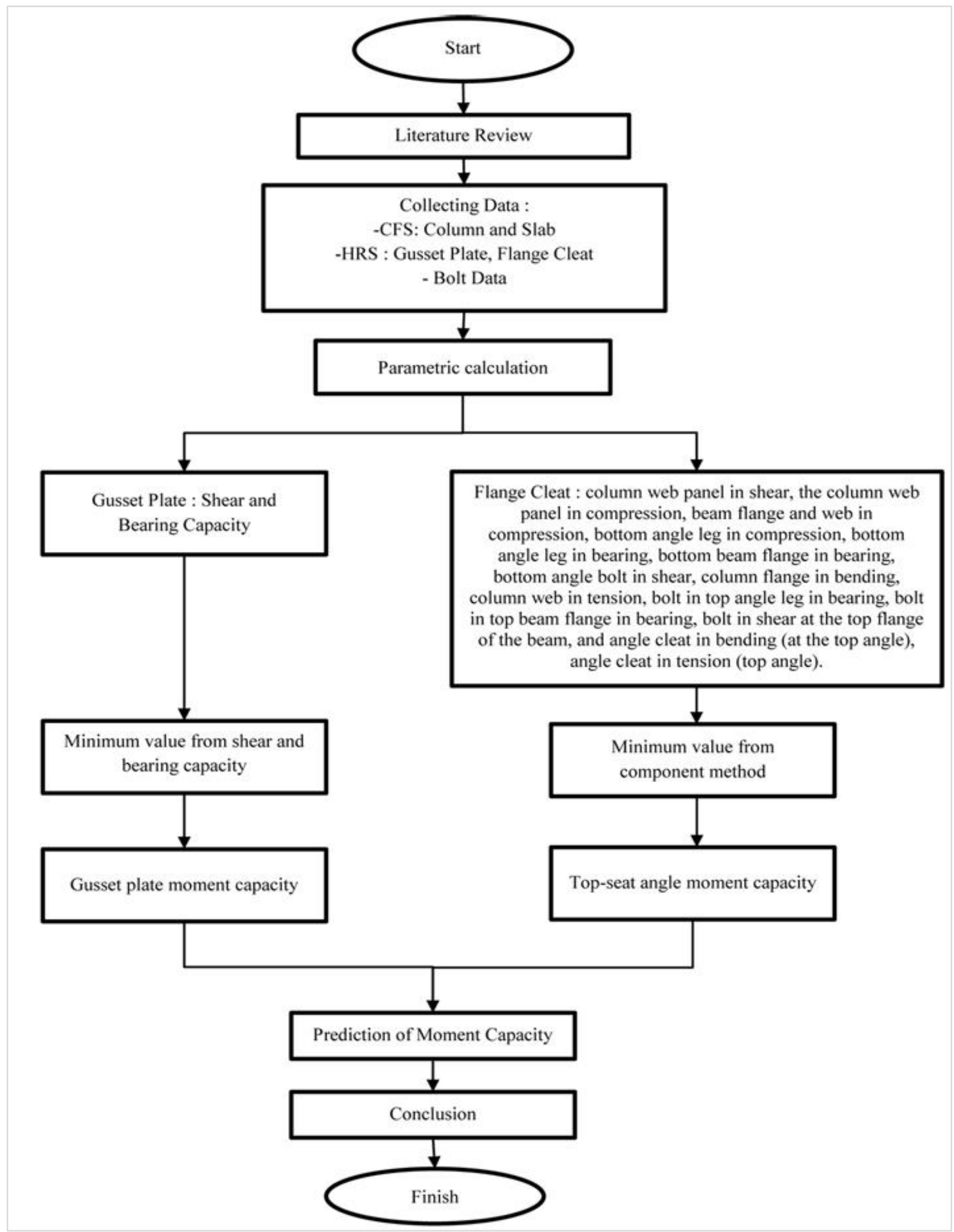

Figure 5 Research flowchart 
Sutanto Muliawan et al.

The column web panel in shear as shown in Equation 1.

$\mathrm{V}_{\mathrm{wp}, \mathrm{Rd}, 1}=\frac{0,9 f_{y c} A_{v c}}{\sqrt{3} \gamma_{M 0}}$

The column web panel with compression (Equation 2 and 3). Minimum of $\mathrm{F}_{\mathrm{cwc}, \mathrm{Rd}}$

$\mathrm{F}_{\mathrm{cwc}, \mathrm{Rd}}=\frac{\omega k_{w c} b_{e f f, c w c} f_{y c} t_{w c}}{\gamma_{M 0}}$

$\mathrm{F}_{\mathrm{cwc}, \mathrm{Rd}}=\frac{\omega k_{w c} \rho_{c w c} b_{e f f, c w c} f_{y c} t_{w c}}{\gamma_{M 1}}$

Beam Flange and $\mathrm{Web}$ in compression (Equation 4) $\left(\mathrm{F}_{\mathrm{c}, \mathrm{fb}, \mathrm{Rd}}\right)$

$\mathrm{F}_{\mathrm{c}, \mathrm{fb}, \mathrm{Rd}, 1}=\frac{M_{b, R d}}{h_{b}-t f b}$

Bottom angle leg in compression (Equation 5) ( $\left.\mathrm{F}_{\mathrm{ca}, \mathrm{fb}, \mathrm{Rd}}\right)$

$\mathrm{F}_{\mathrm{ca}, \mathrm{fb}, \mathrm{Rd}, 1}=$ minimum of $\frac{I_{s a} t_{s a} f_{y s a}}{\gamma_{M 0}}$ or $\frac{\rho_{s a c} I_{s a} t_{s a} f_{y s a}}{\gamma_{M 1}}$

Bottom angle leg in bearing (Equation 6) $\left(\mathrm{F}_{\mathrm{cab}, \mathrm{Rd}}\right)$

$\mathrm{F}_{\mathrm{cab}, \mathrm{Rd}}=\frac{n_{b} k_{1, s a} \alpha_{b, s a} f_{u, s a} d_{b o l t} t_{s a}}{\gamma_{M 2}}$

Bottom beam flange in bearing (Equation 7) $\left(\mathrm{F}_{\mathrm{cbbt}, \mathrm{Rd}}\right)$

$\mathrm{F}_{\mathrm{cbfb}, \mathrm{Rd}, 1}=\frac{n_{b} k_{1, b f} \alpha_{b, b f} f_{u b} d_{b o l t} t_{f b}}{\gamma_{M 2}}$

Bottom angle bolts in shear (Equation 8) ( $\left.\mathrm{F}_{\mathrm{vca}, \mathrm{Rd}}\right)$

$\mathrm{F}_{\mathrm{vca}, \mathrm{Rd}}=\frac{n_{S} \alpha_{v, \text { bolt }} f_{u, \text { bolt }} A_{v, \text { bolt }}}{\gamma_{M 2}}$

Column Flange in Bending (Equation 9 and 10)

$\left(\mathrm{F}_{\mathrm{tc}, \mathrm{Rd} 1}\right)$

Minimum of:

$\mathrm{F}_{\mathrm{tc}, \mathrm{Rd} 1}=\frac{4 M p l, R d}{m c f}$

or

$\mathrm{F}_{\mathrm{tc}, \mathrm{Rd} 1}=\frac{2 M p l, R d+e c f \times \sum F t, R d}{m c f+e c f}$

Column Web in Tension (Equation 11)

$\mathrm{F}_{\mathrm{twc}, \mathrm{Rd}}=\frac{b e f f, t w c \times t w c \times f w c}{\gamma M 0}$

Bolt in Top angle Leg in Bearing (Equation 12)

$\mathrm{F}_{\mathrm{tab}, \mathrm{Rd}}=\frac{n_{b} \times k_{1, t a} \times \alpha_{b, t a} \times f_{u, t a} \times d_{b o l t} \times t_{t a}}{\gamma M 2}$

Bolt in Top Beam Flange in Bearing (Equation 13)

$\mathrm{F}_{\mathrm{tbbb}, \mathrm{Rd}}=\frac{n_{b} \times k_{1, t b f b} \times \alpha_{b, t b f b} \times f_{u, b} \times d_{b o l t} \times t_{f b}}{\gamma M 2}$

Bolt in Shear at the Top Flange of The Beam

The shear resistance of the bolts in the top flange is the same as in the bottom flange (Equation 14).

$\mathrm{F}_{\mathrm{vta}, \mathrm{Rd}}=\mathrm{F}_{\mathrm{vca}, \mathrm{Rd}}$

Angle Cleat in Bending (At the Top Angle (Equation 15,16 and 17))

The minimum of

1012

$$
\begin{aligned}
\mathrm{F}_{\mathrm{ta}, \mathrm{Rd}} & =\frac{4 M_{p l, R d}}{M_{e f f, t a}} \\
& =\frac{2 M_{p l, R d}+e_{2, t a} \times \sum F_{t, R d}}{M_{e f f, t a}+e_{2, t a}} \\
& =\sum F_{t, R d}
\end{aligned}
$$

Angle Cleat in Tension (Top Angle) (Equation 18 and 19)

The minimum of

$$
\begin{aligned}
\mathrm{F}_{\mathrm{ta}, \mathrm{t}, \mathrm{Rd}} & =\frac{{ }_{t a t} t_{t a} f_{y, t a}}{\gamma M 0} \\
& =\frac{\left(I_{t a}-2 d_{0}\right) t_{t a} f_{u, t a}}{\gamma M 2}
\end{aligned}
$$

Based on BS EN 1-8:2005 [26], the bolt resistance is taken from the minimum value of Fbolt. To find the joint flexural resistance (Equation 20) $\left(\mathrm{M}_{\mathrm{j}, \mathrm{Rd}}\right)$

$\mathrm{M}_{\mathrm{j}, 3}=$ Minimum $\mathrm{F}_{1, \mathrm{Rd}} \mathrm{x}$ lever of arm $\mathrm{x}$ number of flange cleat

The full-scale isolated joint test configuration instrument is shown in Figure 6. The hydraulic jack and the load cell are installed at the end of the slab with a $900 \mathrm{~mm}$ distance. The load applied to the specimen is about $0.2-0.5 \mathrm{kN}$. Increasing the load will directly cause the deformation to increase.

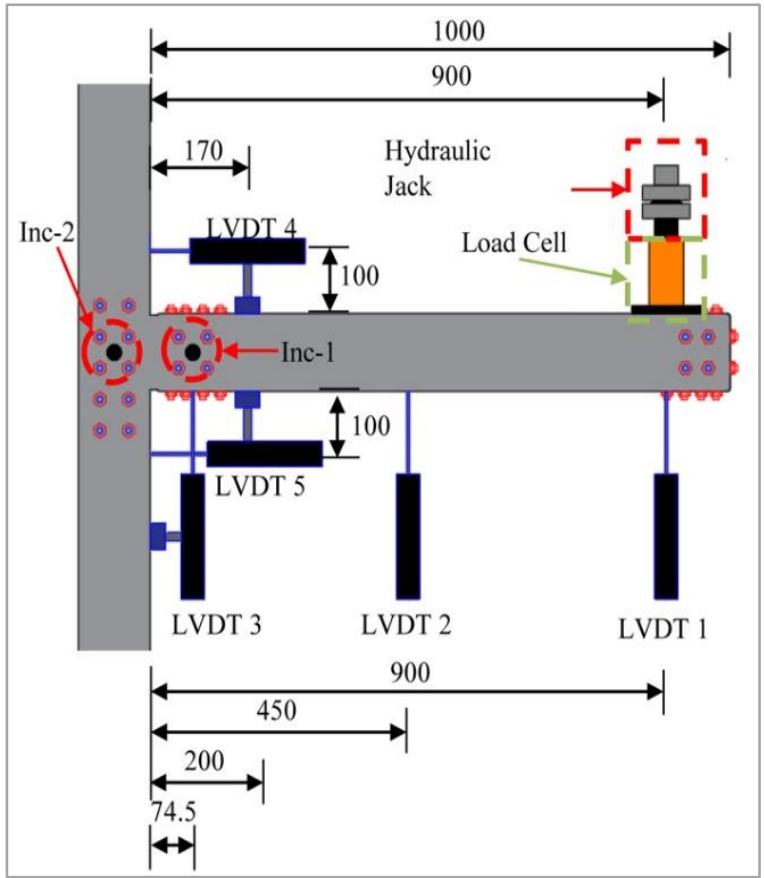

Figure 6 Isolated joint test set-up

There are two Inclinometers installed at the specimen. Inc-1 is the inclinometer placed on the slab, and Inc-2 is the inclinometer placed on the column. The inclinometer is helpful to measure the rotation that 
occurred to the specimen. Location of Inc-1 is placed in the middle of the slab bolt group, and the Inc- 2 is placed parallel to the Inc-1.

There are five Linear Variable Differential Transformers (LVDT) placed at the specimens. LVDT 1 locates under the slab and parallel to the applied load. The location of LVDT 2 is in the middle of the slab. Below the Inc-1 was LVDT 3. LVDT-4 and LVDT -5 are located horizontally toward the column. The distance of LVDT 4 and 5 to the slab is $100 \mathrm{~mm}$. There are some limitations in this study: the noncomposite connection, only focus on column-slab connection, cold-formed steel material for column and slab component. The usage of top-seat angle in the connection, and only calculate the moment capacity based on Eurocode 3 standard, and the applied load is static.

\section{Result}

4.1IJT-03 specimen calculation

4.1.1Gusset plate calculation

In the gusset plate part, there was a shear and bearing capacity calculation. The calculation is shown below.

$\mathrm{F}_{\mathrm{v}, \mathrm{Rd}}=\frac{\alpha_{v} f_{u b} A_{s}}{\gamma_{M 2}}=\frac{0.6 \times 800 \times 58}{1.25}=22.272 \mathrm{kN}$

$$
\begin{gathered}
\mathrm{F}_{\mathrm{b}, \mathrm{Rd}, \mathrm{Cfs}}=\quad \frac{2.5 \alpha_{b} k_{t} f_{u, \text { beam }} d_{\text {bolt }} t_{f, \text { beam }}}{\gamma_{M 2}} \\
\begin{array}{c}
\frac{2.5 \times 590 \times 10 \times 2.36}{1.25}=27.848 \mathrm{kN} \\
\mathrm{F}_{\mathrm{b}, \mathrm{Rd}, \mathrm{gp}}=\frac{2.5 \alpha_{b} k_{t} f_{u, g} d_{\text {bolt }} t_{g}}{\gamma_{M 2}}=\frac{2.5 \times 510 \times 10 \times 4}{1.25} \\
=40.8 \mathrm{kN} \\
\mathrm{F}_{\mathrm{b}, \mathrm{Rd}, \mathrm{ac}}=\frac{2.5 \alpha_{b} k_{t} f_{u, a c} d_{b o l t} t_{a c}}{\gamma_{M 2}}=\frac{2.5 \times 510 \times 10 \times 4}{1.25} \\
=40.8 \mathrm{kN}
\end{array}
\end{gathered}
$$

The capacity of the gus set plate connection depends on the minimum value between shear and bearing capacity. The shear resistance is influenced by the number of shear and bearing planes. The shear and bearing capacity calculation in the side and middle parts of the specimen is summarized in Table 2. The total moment capacity between the side and middle part of the specimen is matched with the previous study [7].

Table 2 The capacity of gusset plate

\begin{tabular}{lllllll}
\hline & Component & $\begin{array}{l}\text { Bearing } \\
\text { plane }\end{array}$ & $\begin{array}{l}\text { Shear } \\
\text { plane }\end{array}$ & $\begin{array}{l}\text { Bearing } \\
\text { capacity } \\
(\mathbf{k N})\end{array}$ & $\begin{array}{l}\text { Shear capacity } \\
(\mathbf{k N})\end{array}$ & $\begin{array}{l}\text { Moment } \\
\text { capacity } \\
(\mathbf{k N m})\end{array}$ \\
\hline & Bolt & - & - & 44.544 & - \\
Side Gusset & Cold-formed Steel & 1 & - & 27.848 & - & - \\
Plate & Gusset Plate & 1 & - & 40.8 & - & - \\
& Angle Clamp & 1 & - & 40.8 & - & - \\
& Bolt & - & 2 & - & - & - \\
Middle & Cold-formed Steel & 2 & - & 55.7 & 2 & - \\
Gusset Plate & Gusset Plate & 1 & - & 40.8 & - & - \\
Moment & Connection & - & - & - & - & 17.11 \\
\hline
\end{tabular}

\subsubsection{Flange cleat calculation}

The results are shown in Table 3 based on Equation 1 to Equation 19. It selects from the minimum resistance from the overall calculation. It was then multiplied by the lever arm in equation 20. Figure 7 shows the location of the failure mode in the connection. Each failure mode has influenced by either it is by the tension zone or the compression zone. The equation 1 until equation 19 is related to Figure 7 . So, the minimum value from the calculation shows the failure location where the failure mode occurred.

The minimum value obtained is $4.17 \mathrm{kN}$ with failure modes in angle cleat in bending (top angle) for the moment resistance as calculated below.

$$
\begin{aligned}
\mathrm{M}_{\mathrm{j}, 3} & =4.17 \mathrm{kN} \times 256 \mathrm{~mm} \times 12 \\
& =12.8 \mathrm{kNm} \\
& =17.11+12.8 \\
& =29.91 \mathrm{kNm}
\end{aligned}
$$


Sutanto Muliawan et al.

The comparis on results between IJT-01, IJT-02, IJT03 are presented in Table 4. It is shown that the moment capacity of connection has improved in IJT-
02 and IJT-03. The installation of a top-seat angle could improve the moment capacity well.

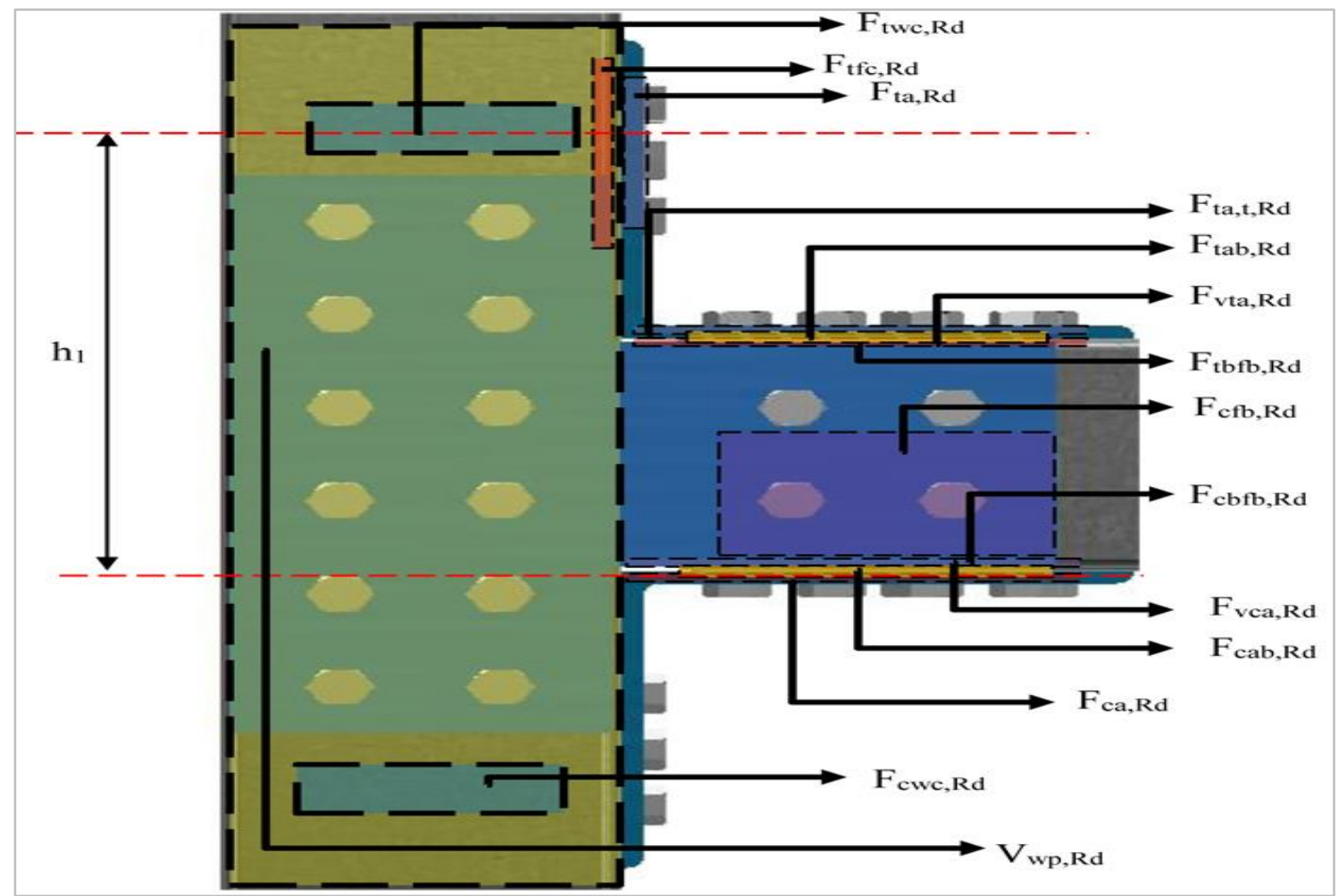

Figure 7 Top angle and seat angle in IJT-03

Table 3 Summarize calculation in IJT-03

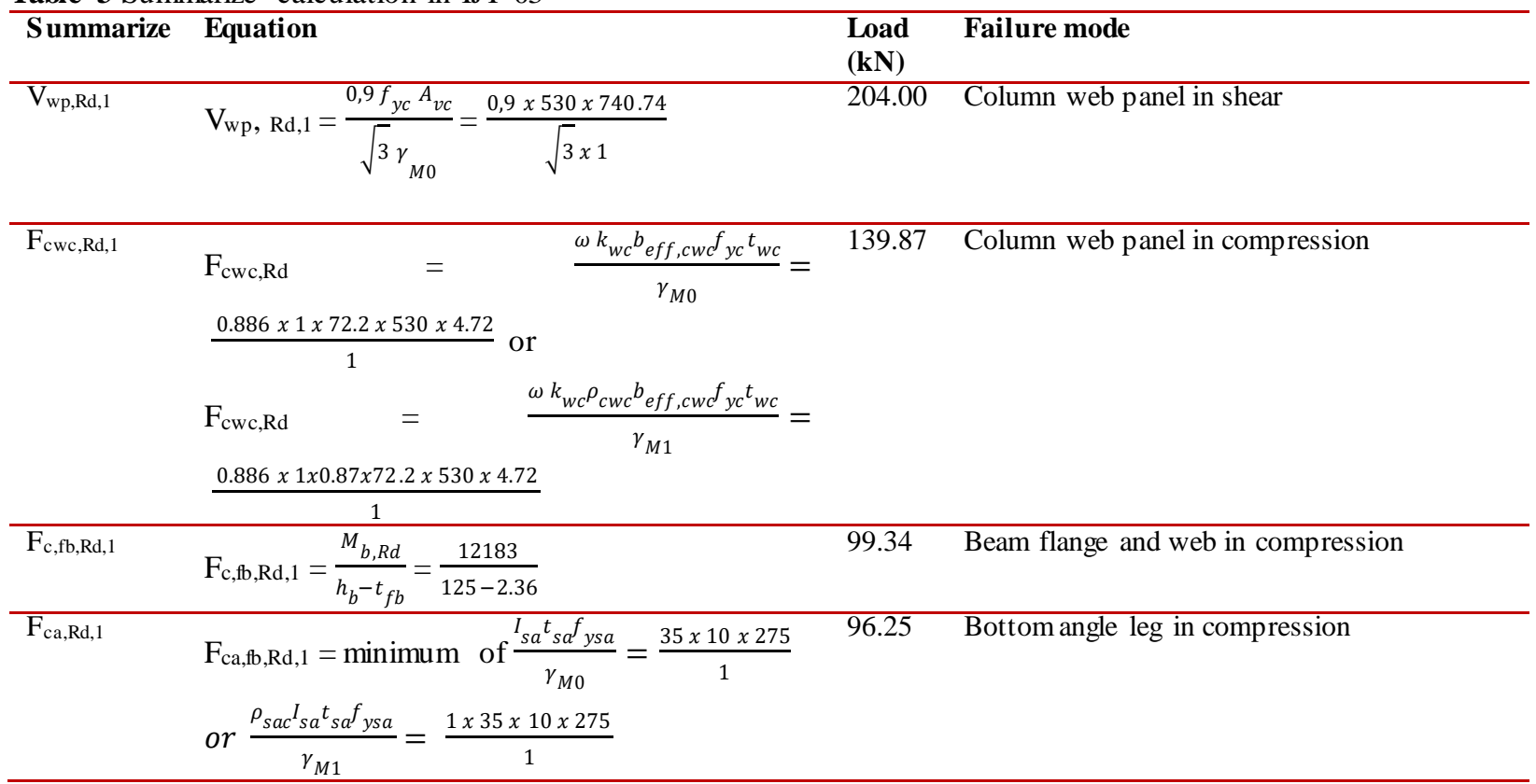




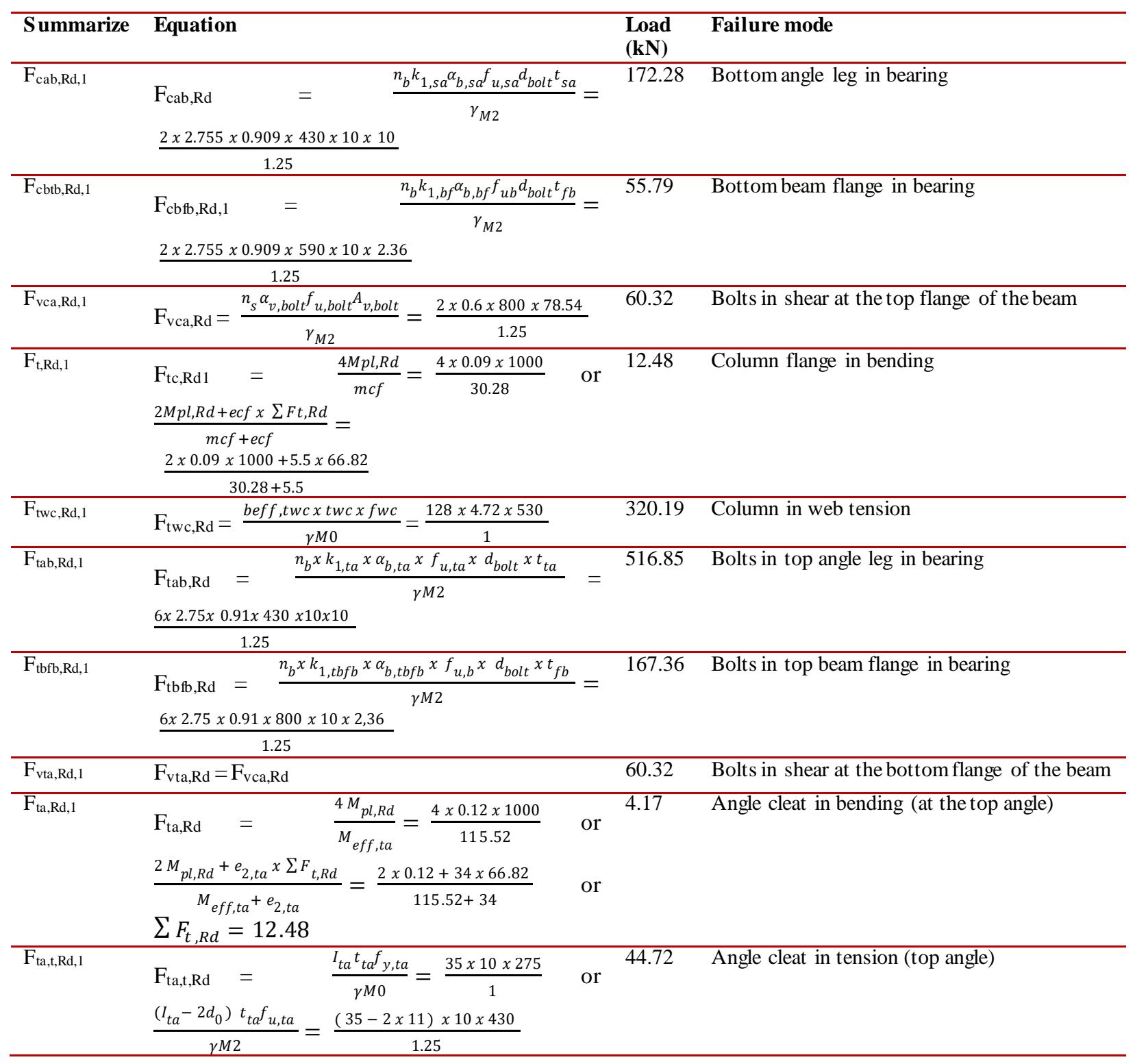

Table 4 Moment capacity comparison

\begin{tabular}{llllll}
\hline IJT-01 & \multicolumn{3}{l}{ IJT-02 } & IJT-03 & \\
\hline Moment capacity & Shear capacity & Moment capacity & Shear capacity & Moment capacity & Shear capacity \\
\hline 17.11 & 44.544 & 23.32 & 66.82 & 29.91 & 89.088 \\
\hline
\end{tabular}

\section{Discussion}

The bearing failure happens at the bolt holes in a single CFS section of the outer side of all specimens. The bolt's bearing resistance is smaller than the other connection component. The possibility of bearing failure at the gusset plate will happen in the middle part of the specimen. There is a small possibility that shear failure will happen at the side and middle part of

1015 the specimen because the bolt has a high strength resistance.

In the IJT-03 calculation, there was a calculation method of each failure mode with the top and seat angle. There are 14 possible failure modes that can happen. The minimum value presents the possible failure. The possible failure will be happened at the angle cleat due to the bending at top angles at loading resistance of $4.17 \mathrm{kN}$. The failure will happen at the 
Fta, Rd, 1 because it has the smallest bending resistance value compared to other failure modes. The other possible failure mode will happen at the column flange in bending $(\mathrm{Ft}, \mathrm{Rd})$ because it has $12.48 \mathrm{kN}$ in load resistance. At the top angle, two possibilities of failure mode will happen, and at the seat angle will happen the failure mode at the bottom beam flange with the bearing load resistance of $55.79 \mathrm{kN}$.

The moment capacity in IJT-03 has a more significant value rather than the previous type of connection. Th is calculation showed that the top and seat angles instalment improved the moment capacity of the connection. The additional top and seat angles resist the connection both in the tension and compression zones. It showed by the 14 possible failure mode was around the tension and compression zone of the connection. The tension zone in IJT-03 is more substantial than in IJT-02 because IJT-02 does not have a top angle in the tension zone.

The shear capacity of the bolts within the connection have shear capacity that is influenced by the shear plane. Each flange cleat has one shear plane. The shear capacity is consistently increased along with the addition of a flange cleat in the connection. The IJT03 has a bigger shear capacity than IJT-02 and IJT-01. The shear resistance of all specimen's connection is stronger than the bearing resistance. Complete list of abbreviations is shown in Appendix I.

\section{Conclusion and future work}

Based on this research, it could be concluded that the result of the IJT-01 specimen shows that the bearing failure is more determined than the shear failure. The high-strength bolts used in the connection are enough to resist the shear failure. The bearing failure is affected by other components such as the gusset plate, cold-formed steel, and seat angle. The possible bearing failure will happen at the side part of the specimen because it just had one bearing plane. In the middle part, the possible bearing failure was on the gusset plate. The failure mode of IJT-03 is caused by angle cleat in bending (top angle) with a load resistance of $4.17 \mathrm{kN}$. This kind of failure mode could be used as the reference in the experimental test. So, the researcher could anticipate the failure or improve the connection capacity. The moment capacity of the connection has improved from IJT-01 to IJT-03, respectively. The installation of the flange cleat at the top and seat location gives the additional moment capacity of the connection. The moment capacity increases $35 \%$ from IJT-01 to IJT-02 and $28 \%$ from
IJT-02 to IJT-03. The maximum moment capacity of the connection is predicted at the value of $29,91 \mathrm{kNm}$.

There are some recommendations for future work. First, the predicted calculation should be followed by the experimental study to verify the result and find the effect of flange cleat installation at the connection between the slab and column subjected to the loading. Second, further study is necessary by using the sub assemblage frame test specimen to observe the relationship between load capacity and the CFS slab panel deflection by using parametric analysis and experimental methods.

Acknowledgment

None

Conflicts of interest

The authors have no conflicts of interest to declare.

\section{References}

[1] Yu WW, Laboube RA, Chen H. Cold-formed steel design. John Wiley \& Sons; 2019.

[2] Dubina D, Landolfo R, Ungureanu V. Design of coldformed steel structures.: Eurocode 3: design of steel structures. part 1-3, Design of cold-formed steel structures. ECCS. 2012.

[3] Aminuddin K, Saggaff A, Tahir MM, Ngian SP, Sulaiman A, Firdaus $M$, et al. Analytical and experimental investigation on slip-in gusset plate connection for double C-channel sections of coldformed steel. The Open Civil Engineering Journal. 2019; 13:210-17.

[4] Aminuddin KM, Saggaff A, Tahir MM, Ngian SP, Sulaiman A, Firdaus M, et al. Behaviour of rectangular gusset plate with angle cleat connections for coldformed steel section. In IOP conference series: materials science and engineering 2020 (pp. 1-8). IOP Publishing.

[5] Firdaus M, Saggaff A, Tahir MM, Aminuddin KM, Ngian SP, Siang TC, et al. Behavior of partial strength of beam-to-column connection with gusset plate for cold-formed steel sections. ASEAN Engineering Journal. 2020; 10(2):99-114.

[6] Hanisha CS, Kishore IS. Experimental and finite element analysis of cold formed steel beam-column joint. Materials Today: Proceedings. 2020; 33(1):4803.

[7] Muliawan S, Saggaff A, Mahmood T, Firdaus M, Aminuddin KM. Loading capacity calculation of integrated precast slab and column panel using coldformed steel. In journal of physics: conference series 2021 (pp. 1-7). IOP Publishing.

[8] Firdaus M, Saggaff A, Tahir MM, Ngian SP, Siang TC, Aminuddin KM, et al. Experimental study on composite connection with double lipped C-sections. In IOP conference series: materials science and engineering 2020 (pp. 1-8). IOP Publishing. 
[9] Amsyar F, Siang TC, Sulaiman A, Khun MC. Numerical and experimental study of semi-rigid beamto-column composite connections in cold-formed steel. In AIP conference proceedings 2020. AIP Publishing LLC.

[10] Sulaiman A, Salleh NM, Sukardi N, Siang TC, Saggaff A. Experimental evaluation of composite beam-tocolumn joint using cold-formed steel sections. In IOP conference series: materials science and engineering 2019 (pp.1-13). IOP Publishing.

[11] Firdaus M, Saggaff A, Tahir MM, Aghlara R, Sulaiman A, Aminuddin K, et al. Influence of seat angles on the behaviour of cold-formed steel concrete composite joints. Journal of Constructional Steel Research. 2020.

[12] Firdaus M, Saggaff A, Tahir M, Ngian SP, Sulaiman A, Salih MN. Experimental and analytical study on composite connection with cold-formed steel of double channel sections. In IOP conference series: materials science and engineering 2019 (pp.1-10). IOP Publishing.

[13] Armo AA, Saggaff A, Tahir MM, Ngian SP, Sulaiman A, Salih MN. Behaviour of rebar shear connector in a push test for composite beam with cold-formed steel section. In IOP conference series: materials science and engineering 2019 (pp.1-10). IOP Publishing.

[14] Salih MN, Tahir MM, Mohammad S, Ahmad Y, Sulaiman A, Shek PN, et al. Experimental study on flexural behaviour of partially encased cold-formed steel composite beams using rebar as shear connector. In IOP conference series: materials science and engineering 2019 (pp.1-8). IOP Publishing.

[15] Tahir MM, Salih MN, Ahmad SA, Shek PN. Behaviour of composite beam arranged as boxed-section with Cchannel of cold-formed steel of lipped section. In IOP conference series: materials science and engineering 2020 (pp.1-9). IOP Publishing.

[16] Lawan MM, Shek PN, Tahir MM. Flexural performance of cold-formed steel section in a composite beam system. In IOP conference series: materials science and engineering 2020 (pp. 1-12). IOP Publishing.

[17] Salih MN, Tahir MM, Mohammad S, Ahmad Y, Shek $\mathrm{PN}$, Abraham A, et al. Bending experiment on a novel configuration of composite sy stem using rebar as shear connectors with partially encased cold-formed steel built-up beams. Materials Today: Proceedings. 2021; 39(2):999-1005.

[18] Muliawan S, Saggaff A, Tahir MB, Firdaus M, Aminuddin KM. Effect of bottom flange cleat on integrated precast slab and column panel using coldformed steel. International Journal of Advanced Technology and Engineering Exploration. 2021; 8(76): 462-72.

[19] Patil MM, Patil SM, Hosur V. Beam-column connections in cold-formed light gauge steel structures. International Research Journal of Engineering and Technology . 2019; 6(5): 6441-8.
[20] Firdaus M, Saggaff A, Tahir MM, Ngian SP, Sulaiman A. Prediction of moment resistance of steel connection with macro excel using Eurocode standard. In journal of physics: conference series 2019 (pp.1-7). IOP Publishing.

[21] Bamaga SO, Tahir MM, Ngian SP, Mohamad S, Sulaiman A, Aghlara R. Structural behaviour of coldformed steel of double C-lipped channel sections integrated with concrete slabs as composite beams. Latin American Journal of Solids and Structures. 2019; 16(5):1-15.

[22] Shi Y, Yang K, Guan Y, Yao X, Xu L, Zhang H. The flexural behavior of cold-formed steel composite beams. Engineering Structures. 2020.

[23] Lawan MM, Shek PN, Tahir MM. Can cold-formed steel section be use as a sustainable structural member in building and civil engineering constructions? a mini review. In IOP conference series: materials science and engineering 2020 (pp.1-13). IOP Publishing.

[24] Qiao W, Yan X, Zhu R, Wang F, Wang D. Flexural properties of new cold-formed thin-walled steel and concrete composite slabs. Journal of Building Engineering. 2020.

[25] Puluhulawa I. Behavior of shear connector variations on strengthened reinforced concrete slabs using cold formed steel. In IOP conference series: earth and environmental science 2020 (pp. 1-7). IOP Publishing.

[26] Standard B. Eurocode 3-design of steel structures-. BS EN 1993-1. 2006; 1:2005.

[27] https://shop.bsigroup.com/products/eurocode-3design-of-steel-structures-general-rules-and-rules-forbuildings?pid $=000000000030283899$. Accessed 24 June 2021.

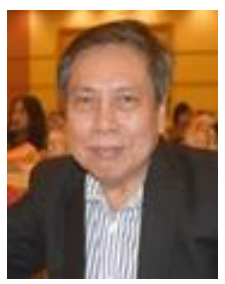

Sutanto Muliawan is a $\mathrm{PhD}$ student of Civil Engineering, Faculty of Engineering, Sriwijay a University. He is a lecturer in the Civil Engineering Department, Faculty of Engineering, Sriwijaya University, Indonesia. His research focuses on Foam Concrete, Cold-Formed Steel, and Light-weight

Construction.

Email: sutantomuliawan@yahoo.com

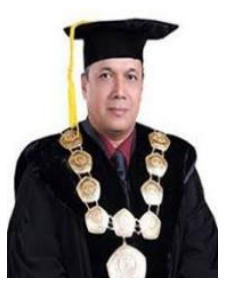

Anis Saggaff is a Professor in the Civil Engineering Department, Faculty of Engineering, Sriwijaya University, Indonesia. He received a Doktor in Civil Engineering from University Teknologi Malaysia. He is Rector of Sriwijaya University. His research focuses on Geopolymer Concrete, Nanomaterial Concrete, Lightweight Concrete, Reactive Powder Concrete, Self Compacting Concrete, Cold-Formed Steel, and LightWeight Construction.

Email: anissaggaf@yahoo.com 


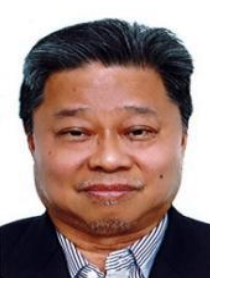

Mahmood Bin Md Tahir is a lecturer at Institute for Smart Infrastructure ad Innovative Construction (ISIIC), Construction Research Centre (CRC), School of Civil Engineering, Universiti Teknologi Malaysia, Johor Bahru, Malaysia. His research focuses on Lightweight Concrete, Cold-Formed Steel, and Light-weight Construction.

Email:mahmoodtahir@utm.my

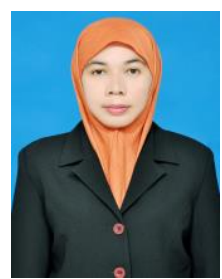

Saloma is a lecturer in the Civil Engineering Department, Faculty of Engineering, Sriwijaya University, Indonesia. She received a Doktor in Civil Engineering from Institut Teknologi Bandung in 2014. She is Head of Graduate of Civil Engineering at Sriwijaya University. Her research focuses on Geopolymer Concrete, Nanomaterial Concrete, Lightweight Concrete, Reactive Powder Concrete, Self Compacting Concrete, Cold-Formed Steel, and Light-weight Construction.

Email: salomaunsri@gmail.com

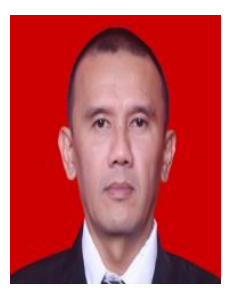

Muhammad Firdaus is a lecturer in Civil Engineering Department, Faculty of Engineering, Universitas Persatuan Guru Republik Indonesia, Palembang, Indonesia. He received a Doktor in Civil Engineering from Sriwijaya University in 2019. His research focuses on Lightweight Concrete, Self Compacting Concrete, Cold-Formed Steel, and Light-weight Construction.

Email: firdaus@univpgri-palembang.ac.id

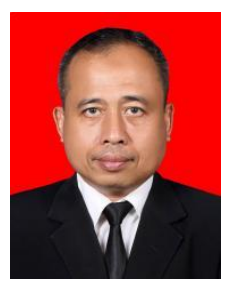

KM Aminuddin is a lecturer in the Civil Engineering Department, Faculty of Engineering, Sriwijaya University, Indonesia. He received a Doktor in Civil Engineering from Sriwijaya University in 2019. His research focuses on Lightweight Concrete, Cold-Formed Steel, and Light-weight Construction.

Email: kmaminuddin@ft.unsri.ac.id

\begin{tabular}{llll}
\multicolumn{2}{l}{ Appendix I } & \\
\hline S. No. & Abbre viation & Description & \\
\hline 1 & CFS & Cold-formed Steel & \\
\hline 2 & GSU & $\begin{array}{l}\text { Gypsum-based } \\
\text { Underlayment }\end{array}$ & Self-leveling \\
\hline 3 & HRS & Hot-Rolled Steel & \\
\hline 4 & IJT & Isolated Joint Test & \\
\hline 5 & LCFA & $\begin{array}{l}\text { Lightweight Concrete with Fine } \\
\text { Aggregate }\end{array}$ & \\
\hline 6 & LVDT & $\begin{array}{l}\text { Linear Variable } \\
\text { Transformers }\end{array}$ & Differential \\
& & &
\end{tabular}

